\title{
International Committee on Systematic Bacteriology Subcommittee on the Taxonomy of the Genus Pseudomonas and Related Organisms
}

\author{
Minutes of the Meetings, 17 and 20 September 1990, Osaka, Japan
}

Session 1. Closed meeting.

Minute 1. Call to order. The meeting was called to order by the Chairman, T. Bergan (Oslo, Norway), at 1800 on 17 September 1990 at the International House, Osaka, Japan.

Minute 2. Record of attendance. The members present were T. Bergan (Chairman and Secretary), N. J. Palleroni, and E. Yabuuchi. Apologies had been received from J. De Ley, M. S. Hendrie, D. Hildebrand, and C. L. Poh. No communication had been received from R. H. W. Schubert.

Minute 3. Previous meeting. No matters were pending from the previous meeting.

Minute 4. Changes in membership and officers. The resignations of Subcommittee members M. S. Hendrie and R. H. W. Schubert were accepted with regret. Because it was known that the attendance at this meeting would be unusually low, a mail ballot vote had been organized. T. Bergan, J. De Ley, M. S. Hendrie, D. Hildebrand, N. J. Palleroni, C. L. Poh, and E. Yabuuchi responded to this ballot. T. Bergan was elected Chairman and E. Yabuuchi was elected Secretary for the next 4 years, until the meeting of the International Union of Microbiological Societies in Czechoslovakia in 1994. All nominations for new members were seconded, and the new members were elected unanimously. The new members elected were P. C. Fahy (Australia), E. Falsen (Sweden), P. Grimont (France), H. Oyaizu (Japan), D. E. Stead (United Kingdom), and P. De Vos (Belgium). The remaining members had expressed their willingness to continue to serve as active members of the subcommittee. Thus, the members of the subcommittee are as follows: T. Bergan (Norway) (Chairman), E. Yabuuchi (Japan) (Secretary), J. De Ley (Belgium), P. De Vos (Belgium), E. Falsen (Sweden), P. C. Fahy (Australia), P. Grimont (France), D. Hildebrand (United States), N. J. Palleroni (United States), C. L. Poh (Singapore), H. Oyaizu (Japan), and D. E. Stead (United Kingdom).

Minute 5. Proposal concerning Xanthomonas citri and Xanthomonas phaseoli. A copy of a manuscript had been sent to the subcommittee for discussion through J. M. Young at the request of R. G. E. Murray. This manuscript was entitled "Comment on the Reinstatement of Xanthomonas citri (ex Hasse 1915) Gabriel et al. 1989 and X. phaseoli (ex Smith 1897) Gabriel et al. 1989; an indication of the need for minimal standards for the genus Xanthomonas," and the authors were J. F. Bradbury (United Kingdom), L. Gardan (France), R. I. Gvozdyak (USSR), D. E. Stead (United Kingdom), Y. Takikawa (Japan), A. K. Vidaver (United States), and J. M. Young (New Zealand) (Chairman of the Subcommittee on Taxonomy of Plant Pathogenic Bacteria of the International Society for Plant Pathology). The subcommittee rejected the proposal to reinstate $X$. citri and $X$. phaseoli as species of the genus Xanthomonas, since the manuscript was not considered a formal proposal to revive the names of the two species. Furthermore, the manuscript contained only the results of a conventional examination and no genomic data, which are now indisensable for taxonomic research on bacteria. The subcommittee agreed that $X$. campestris pv. citri and $X$. campestris pv. phaseoli should continue to be recognized as pathovars, pending the results of further extensive DNA-DNA relatedness studies. This conclusion is consistent with the results of Vauterin et al. (Int. J. Syst. Bacteriol. 40:312-316, 1990).

Minute 6. Status of the genus Sphingomonas. In a recent paper by Yabuuchi et al. (Microbiol. Immunol. 34:99-119, 1990 ) entitled "Proposals of Sphingomonas paucimobilis gen. nov. and comb. nov., Sphingomonas parapaucimobilis sp. nov., Sphingomonas yanoikuyae sp. nov., Sphingomonas adhaesiva sp. nov., Sphingomonas capsulata comb. nov., and Two Genospecies of the Genus Sphingomonas" Pseudomonas paucimobilis was reclassified. The type species of the genus Sphingomonas is Sphingomonas paucimobilis, whose type strain is strain GIFU 2395 (= NCTC 1103). The type strains of the other species of this genus were proposed in the paper mentioned above. The names of the genus and the three new species were validated in Validation List no. 34 (Int. J. Syst. Bacteriol. 40:320, 1990). The published descriptions of the new species serve as the official descriptions for the subcommittee as well.

Minute 7. Comamonas. The genus Comamonas is accepted as a new taxon under the auspices of the subcommittee.

Minute 8. Status of the genus Comamonas. The genus $\mathrm{Co}-$ mamonas as revived and emended by De Vos et al. (Int. J. Syst. Bacteriol. 35:443-453, 1985) is accepted as a new taxon under the auspices of the subcommittee.

Minute 9. Adjournment. The meeting was adjourned at 1930 on 17 September 1990.

\section{Session 2. Open meeting.}

Minute 10. Call to order. The meeting was called to order by the Chairman, T. Bergan, at 1000 on 20 September 1990 at the International House, Osaka, Japan. Attending were all of the subcommittee members who were present at the closed meeting held on 17 September 1990 and an outside participant.

Minute 11. Summary. A summary of the proceedings of the closed meeting held on 17 September 1990 was presented.

Minute 12. Agenda. The two presentations described below were planned for the open meeting. N. J. Palleroni presented a report entitled "Overview of the Current State of the Taxonomy of Pseudomonas and Related Organisms." The internal heterogeneity of the genus Pseudomonas was discovered in 1973 by Palleroni and his collaborators, who used a novel experimental approach, RNA-DNA hybridization. Five rRNA homology groups were clearly defined. One of the groups (group V) was made up of Pseudomonas maltophilia strains and was found to be related to the plant-pathogenic members of the genus Xanthomonas, while group I and V organisms exhibited some rRNA homology with the enteric bacteria. Findings by workers in other laboratories proved that this approach was very appropriate for evaluating distant relationships among bacteria, and a new system for phylogenetic classification of prokaryotes was soon developed. After the discovery of the heterogeneity of the genus Pseudomonas, which suggested that this taxon was actually a multigeneric entity, the necessity of assigning many Pseudomonas species to other genera became obvious. This objective is gradually being achieved by workers in various laboratories. Some examples are the transfer of Pseudomonas maltophilia to the genus Xanthomonas (Swings et al., Int. J. Syst. Bacteriol. 33:409-413, 1983), the 
assignment of Pseudomonas acidovorans and Pseudomonas testosteroni to the genus Comamonas (Tamaoka et al., Int. J. Syst. Bacteriol. 37:52-59, 1987), and the creation of a new genus, the genus Hydrogenophaga (Willems et al., Int. J. Syst. Bacteriol. 39:319-333, 1989), to accommodate the hydrogen pseudomonads Pseudomonas flava, Pseudomonas pseudoflava, and Pseudomonas palleronii. The recent proposal of the new genus Sphingomonas by Yabuuchi and his collaborators for $P$. paucimobilis and related species is another step in the same direction. The changes described above will inevitably be followed by others. Ideally, proposals should be based on clear definitions by means of which taxa can be distinguished from one another, even though they may share all of the major properties included in the current definition of the classical genus Pseudomonas. The second presentation was a report entitled "Cellular Lipid Composition of Pseudomonas Species in rRNA Homology group II," presented by E. Yabuuchi. It is known that the members of the current genus Pseudomonas are going to be classified in several genera. In bacterial taxonomy cellular lipid composition and fatty acid composition are thought to be important criteria for classification of bacteria. The type strains of all seven species belonging to Pseudomonas rRNA homology group II (N. J. Palleroni, in Bergey's Manual of Systematic Bacteriology, vol. 1, 1984) were studied to determine their cellular lipid and fatty acid compositions, which were compared with the cellular lipid and fatty acid compositions of the type strain of the type species, Pseudomonas aeruginosa. Cellular lipids extracted from wet cells were separated by two-dimensional thin-layer chromatography on Silica Gel G plates. The spots were visualized with either a ninhydrin solution, Dittmer reagent, or sulfuric acid and were compared with the spots of standard substances. The major spots were eluted from the plate and analyzed by fast-atom bombardment mass spectrometry. The cellular fatty acid methyl esters, which were obtained by hydrolyzing wet cells with $3 \% \mathrm{HCl}$-methanol at $80^{\circ} \mathrm{C}$ for 24 $\mathrm{h}$, were analyzed by gas-liquid chromatography and gas-liquid chromatography-mass spetrometry. The cellular lipids of all seven species contained characteristic phosphatidylethanolamine (phospholipid PE-2), which has a $2 \mathrm{OH}$ fatty acid at the second position of the glycerol moiety. In five species (all species examined except Pseudomonas solanacearum and Pseudomonas pickettii) two ornithine lipids (OL-1 and OL-2) were found. The cellular lipids of the type strain of $P$. aeruginosa included none of the PE-2, OL-1, and OL-2 components. $3 \mathrm{OH}-\mathrm{C}_{14: 0}$ was the most common cellular fatty acid in all seven species, in contrast to the fatty acid pattern of the type strain of $P$. aeruginosa. These findings are part of the evidence which separates rRNA homology group II from the genus Pseudomonas.

Minute 13. Adjournment. The meeting was adjourned at 1130 on 20 September 1990.

E. Yabuuchi, Secretary P. De Vos 